\title{
Evaluation of Seed Protein Content in USDA Cowpea Germplasm
}

\author{
Yuejin Weng \\ Department of Horticulture, University of Arkansas, Fayetteville, AR 72701
}

Jun Qin

Department of Horticulture, University of Arkansas, Fayetteville, AR 72701; and Hebei Academy of Agricultural and Forestry Sciences, Shijiazhuang, Hebei 050031, China

\section{Stephen Eaton \\ University of Arkansas Vegetable Research Station, 3810 Thornhill Street, Alma, AR 72921}

\section{Yufeng Yang}

Department of Horticulture, University of Arkansas, Fayetteville, AR 72701; and Cereal Crop Institute, Henan Academy of Agricultural Sciences, Zhengzhou, Henan 450002, China

\author{
Waltram Second Ravelombola and Ainong Shi ${ }^{1}$ \\ Department of Horticulture, University of Arkansas, Fayetteville, AR 72701
}

Additional index words. Vigna unguiculata, germplasm evaluation

\begin{abstract}
Cowpea [Vigna unguiculata (L.) Walp] is an annual legume crop grown worldwide to provide protein for human consumption and animal feed. The objective of this research was to evaluate the seed protein content in U.S. Department of Agriculture (USDA) cowpea germplasm for use in cowpea breeding programs. A field experiment was conducted with a randomized complete block design (RCBD) with three duplications in two locations, Fayetteville and Alma, in Arkansas, United States. A total of 173 USDA cowpea accessions were evaluated with the Elementar Rapid N analyzer III for their seed protein contents. The results showed that there was a wide range of seed protein content among the 173 cowpea genotypes, ranging from $22.8 \%$ to $28.9 \%$ with an average of $25.6 \%$. The broad-sense heritability for seed protein among the 173 cowpea genotypes was $50.8 \%$, indicating that seed protein content was inheritable and can be selected in breeding processing. The top five cowpea accessions with the highest seed protein contents were USDA accession PI 662992 originally collected from Florida (28.9\%), PI 601085 from Minnesota (28.5\%), and PI 255765 and PI 255774 from Nigeria and PI 666253 from Arkansas (28.4\% each). PI 339587 from South Africa had the lowest protein content with $21.8 \%$. The were also significant differences in seed protein contents observed among different seedcoat colors; the accessions with cream color exhibited higher protein content $(27.2 \%)$ than others. This research could provide information for breeders to develop cowpea cultivars with higher seed protein content in a cowpea breeding program.
\end{abstract}

Cowpea [Vigna unguiculata (L.) Walp], an annual legume native to tropical and subtropical regions, is a protein-rich crop that complements staple cereal for human and fodder for livestock and also provides soil improvement benefits through nitrogen fixation. Cowpeas are commonly grown in the semiarid tropics between $35 \mathrm{~N}$ to $30 \mathrm{~S}$ of the equator, covering Africa, Asia, Oceania, the Middle East, Southern Europe, Central and South America, and the southern United States. The African countries of Nigeria and Niger account for $66 \%$ of world production. It is estimated that cowpeas are cultivated on 12.56 million hectares and have a worldwide

Received for publication 29 Jan. 2019. Accepted for publication 12 Mar. 2019.

${ }^{1}$ Corresponding author. E-mail: ashi@uark.edu. production of 5.55 million tons; they are consumed by 200 million people on daily basis in the 20 countries with highest cowpea cultivation (Boukar et al., 2018; Singh et al., 1997).

Cowpea can be used at all stages of growth (Fang et al., 2007; Nielsen et al., 1997). The green seeds can be used fresh or canned or frozen for humans. The young leaves, pods, and peas contain vitamins and minerals, which are used for human consumption and animal feed. Cowpea can be consumed as dry seeds, canned or frozen food (Fery, 1993), and as milling flour in baked goods (Kushwaha and Kumar, 2014). The seeds are also used for human consumption as an affordable source of protein and a supplemental fodder for livestock. In addition, cowpea has been used as an alternative to soybean for people who are allergic to soybean protein (Boukar et al., 2018).
Like soybean, cowpea is nutritious with $\approx 23 \%$ protein in dry seeds, which could meet the increasing consumer demand for healthier and more nutritious food. Unlike soybean, cowpea proteins do not cause allergies and are of higher quality when substituted in diets at equivalent protein contents. In recent years, there has been increasing interest in breeding cowpea cultivars with high seed protein content to improve nutritional quality. Evaluation of seed protein content in cowpea germplasm will help plant breeders select and breed high seed protein content cultivars in breeding programs. Asante et al. (2006) reported that protein content averaged $27.3 \%$ among 32 accessions. Gupta et al. (2010) screened 21 cowpea genotypes and observed that total protein content ranged from $22.4 \%$ to $27.9 \%$; they found that seven genotypes (viz. HC-6, HC-5, CP-21, LST-IIC-12, CP-16, COVU702, and HC-98-64) had the highest protein contents, ranging from $26.7 \%$ to $27.9 \%$. Itatat et al. (2013) studied 11 cowpea genotypes and reported a range of $20.57 \%$ to $24.95 \%$. Afiukwa et al. (2013) found a greater variability of the total seed protein contents, ranging from $15.06 \%$ to $38.5 \%$, with a mean of $25.99 \%$ in dry seeds among 110 cowpea genotypes. Oke et al. (2015) analyzed five varieties of cowpea and found that seed protein contents ranged from $25.80 \%$ to $28.95 \%$. Ravelombola et al. (2016) assessed 11 cowpea cultivars/breeding lines developed in Arkansas and found an average protein content of $25.4 \%$ (range $23.7 \%$ to $27.4 \%$ ) with a standard deviation of $1.9 \%$. Weng et al. (2017) compared two methods to measure seed protein content and found a large variance among 240 cowpea genotypes.

Germplasm provides the elite gene(s) for breeding program. The objective of this study was to evaluate seed protein content among 173 worldwide cowpea accessions to use the high seed protein cowpea germplasm in cowpea breeding programs to develop superior cowpea cultivars with high seed protein contents.

\section{Materials and Methods}

Plant materials and field experiment. This study included 173 cowpea genotypes. The seeds were obtained from the USDA Germplasm Resources Information Network (GRIN) and increased in the field of University of Arkansas Research and Extension Center at Fayetteville, AR. The field experiments were conducted using a RCBD with three replications in two locations in Arkansas: Fayetteville $\left(36^{\circ} 4^{\prime} \mathrm{N}, 94^{\circ} 9^{\prime} \mathrm{S}\right)$ and Alma $\left(35^{\circ} 29^{\prime} \mathrm{N}, 9^{\circ} 13^{\prime} \mathrm{S}\right)$ (Supplemental Table 1). Each cowpea accession was planted in a single, 14-foot-long row, and the distance between rows (row spacing) was 3 feet. Plant spacing within rows was $\approx 4$ inches. During the growing season, no pesticides, herbicides, or chemicals were sprayed to control pests, disease, or weeds. No irrigation was regularly maintained before maturity. The cowpea pods were bulk harvested when $90 \%$ of 
pods were dried based on differing maturity. The cowpea seeds were shelled and cleaned after pods were harvested.

Seed sample preparation. A total of 1038 samples were collected from the 173 cowpea accessions at the two locations, with three duplications at each location. Before measuring seed protein content, each cowpea genotype was further selected for matured seeds, uniform color and size, and lack of damage from insects or machinery. To have a sufficient quantity of seeds for protein analysis, $\approx 20 \mathrm{~g}$ of cowpea seeds from each sample were ground using a coffee grinder (Hamilton Beach) for $1 \mathrm{~min}$. Approximately $5 \mathrm{~g}$ of the ground powder was sieved through $100 \#$ (nominal wire diameter $0.1 \mathrm{~mm}$ ), and $1 \mathrm{~g}$ of each sample was weighed and then transferred to a $0.2-\mathrm{mL}$ microfuge tube for protein determination by N/protein analyzer.

Seed protein content assessment. Cowpea seed protein content was measured by analyzing the percentage of Nitrogen by combustion using an Elementar Rapid N III instrument at Agriculture Diagnostic Laboratory, University of Arkansas. Each 1.0-g sample was collected and measured for protein content. At high temperature and in the presence of pure oxygen, nitrogen was removed by combustion. The nitrogen was then isolated from other combustion products. A thermal conductivity detector measured the nitrogen content for each sample (Horneck and Miller, 1998). The percentage of nitrogen in each sample was provided, and the total protein content for each sample was estimated by times 6.25 nitrogen (Moore et al., 2010).

Data analysis. Analysis of cowpea seed protein data were performed by analysis variance (ANOVA) using the general linear models procedure of JMP Genomics 7 (SAS Institute, Cary, NC). For comparisons among genotypes, Student's $t$-test was used to perform multiple comparisons for least square mean protein content at $P=0.05$. The mean, range, $\mathrm{SD}, \mathrm{SE}$, and $\mathrm{CV}$ were estimated for seed protein content using Tabulate, and the distributions of protein content was also performed using Distribution in JMP Genomics 7.

On the basis of our experiments in this study, there were 173 cowpea genotypes growing in two locations using RCBD with three blocks (replications) in each location. ANOVA for seed protein contents among the 173 cowpea genotypes was conducted (Table 1 ) using the two-way genotype $\times$ environment (GE) model suggested by Singh et al. (1993). The broad-sense heritability $\left(\mathrm{H}^{2}\right)$ was estimated using the formula.

$$
\begin{aligned}
\mathrm{H}^{2} & =100 *\left(\sigma_{\mathrm{G}}^{2} / \sigma_{\mathrm{P}}^{2}\right) \\
& =100 *\left(\sigma_{\mathrm{G}}^{2} /\left(\sigma_{\mathrm{G}}^{2}+\sigma_{\mathrm{GE}}^{2}+\sigma_{\mathrm{e}}^{2}\right)\right),
\end{aligned}
$$

where $\sigma_{P}^{2}$ is phenotypic variance, $\sigma^{2}{ }_{G}$ is genotypic variance, $\sigma^{2}{ }_{\mathrm{GE}}$ is genotype $\times$ environment variance, and $\sigma^{2}$ is variance associated with the experimental error. $\sigma^{2}{ }_{G}$, $\sigma^{2}{ }_{\mathrm{GE}}$, and $\sigma_{\mathrm{E}}^{2}$ were obtained using the following formula:

$$
\begin{aligned}
\sigma_{\mathrm{G}}^{2} & =(\mathrm{MSG}-\mathrm{MSGE}) / \mathrm{bL}, \\
\sigma_{\mathrm{GE}}^{2} & =(\mathrm{MSGE}-\mathrm{MSE}) / \mathrm{b}, \\
\sigma_{\mathrm{e}}^{2} & =\mathrm{MSE},
\end{aligned}
$$

where MSG is mean square genotype, MSGE is mean square $\mathrm{G} \times \mathrm{E}$, and MSE is mean square error. The estimates of MSG, MSGE, and MSE were taken from the ANOVA table; $b$ is the number of blocks ( $b=$ three blocks in this study), and L is the number of locations ( $\mathrm{L}=2$ locations here) (Table 1).

Seed protein content-based seedcoat color In this study, based on the seedcoat color, there were 18 cowpea accessions with black seedcoat, 26 blackeye, 29 browneye, 12 cream, 8 pinkeye, 15 red, 19 red Holstein, 26 tan, and 20 varied (Table 3 ). ANOVA based on seedcoat and multiple comparisons using Student's $t$-test were also analyzed with JMP Genomics 7.

\section{Results and Discussion}

Elite germplasm discovery. Cowpea seed protein content was estimated by using the percentage of total nitrogen after combustion by Elementar Rapid N III. Significant variations were observed for the seed protein content among 173 USDA cowpea accessions (Fig. 1), ranging from $21.8 \%$ to $28.5 \%$ with an average of $25.6 \%$ (Supplemental Table 1; Fig. 1).

The results were in agreement with previous reports for cowpea seed protein content at the $25 \%$ level (Afiukwa et al., 2013; Asante et al., 2006; Boukar et al., 2018; Itatat et al., 2013; Nielsen et al., 1997; Oke et al., 2015; Singh et al., 1997; Ravelombola et al., 2016). The top 10 USDA cowpea accessions with higher protein contents $(\geq 28 \%)$ are listed in Table 2 . Among them, the USDA cowpea accession PI 662992 from Florida had the highest seed protein content with $28.9 \%$ of the dry seed weight. PI 601085 was second highest with $28.5 \%$, collected from Minnesota. The two accessions PI 255765 and PI 255774 from Nigeria and PI 666253 from Arkansas had protein contents as high as $28.4 \%$. PI339587 from South Africa had the lowest protein level $(21.8 \%)$ (Table 2; Supplemental Ta- ble 1). The five cowpea genotypes with high seed protein contents, PI 662992, PI 601085, PI 255765, PI 255774, and PI 666253, could be used in breeding programs aimed at developing varieties with high protein content.

The cowpea is an important food crop in tropical and subtropical regions, but little research has been done on seed protein content in this crop compared with the other legume species such as soybean (Glycine $\max$ L.). Due to limited data on germplasm with high seed protein content available to use in cowpea breeding program, it is necessary to screen cowpea germplasm to find elite genotype(s) with high protein content. Whether the cowpea seeds are used as food for direct human consumption or processed into flour to make baked goods or other products, the protein content of cowpea seeds is an important index closely related to quality, health, nutrition, and market price. Farmers and consumers prefer high-protein varieties and products. Therefore, high protein content has become a goal in cowpea breeding programs and production. Previous studies have confirmed that cowpea seeds in general had a $25 \%$ protein content. It will be valuable to find varieties and germplasm with protein content greater than the average of $25 \%$. Asante et al. (2006) studied the variation in protein content of 32 cowpea accessions in Ghana and found the seed protein content ranged from $16.4 \%$ to $27.3 \%$ with an average of $22.5 \%$. Two among the 32 accessions had seed protein content higher than $25 \%$. 'Bengpla (1)' had the highest with $27.3 \%$, and another breeding line, 87/30, had $26.9 \%$ seed protein content (Asante et al., 2006). Gupta et al. (2010) screened cowpea for total seed protein content in 21 genotypes and found that the seed protein contents ranged from $22.4 \%$ to $27.9 \%$ and reported that 'HC-98-64' had the highest protein content at $27.9 \%$. Ravelombola et al. (2016) evaluated 11 released cowpea cultivars and breeding lines developed in Arkansas and found that the average protein content was $25.4 \%$ (range $23.7 \%$ to $27.4 \%$ ). Cultivar Early Scarlet and the breeding line 09-204 had the highest and the second highest seed protein content with $27.4 \%$ and $26.9 \%$ dry seed weight, respectively (Ravelombola et al., 2016). In the current study, more than 10 elite USDA cowpea accessions were found to have high seed protein content of greater than $28.4 \%$, which is higher than regular commercial cowpea cultivar(s) (Table 1; Supplemental Table 1);

\begin{tabular}{|c|c|c|c|c|c|c|c|c|}
\hline Source & $\mathrm{df}$ & Sum of squares & Mean square & $\mathrm{F}$ & Prob $>F$ & EMS & MS symbol & Variance \\
\hline Environment (E) & $\mathrm{L}-1=1$ & \multirow{2}{*}{\multicolumn{7}{|c|}{$\begin{array}{l}\text { Not relevant } \\
\text { Not relevant }\end{array}$}} \\
\hline Blocks/Env & $(b-1) L=4$ & & & & & & & \\
\hline Genotype (G) & $\mathrm{v}-1=172$ & 2429.31 & 14.12 & 14.74 & $<0.0001$ & $\sigma_{\mathrm{e}}^{2}+\mathrm{b} \sigma_{\mathrm{GE}}^{2}+\mathrm{bL} \sigma_{\mathrm{G}}^{2}$ & MSG & $\sigma_{\mathrm{G}}^{2}=1.80$ \\
\hline $\mathrm{G} \times \mathrm{E}$ & $(\mathrm{v}-1)(\mathrm{L}-1)=172$ & 566.76 & 3.30 & 3.44 & $<0.0001$ & $\sigma_{\mathrm{e}}^{2}+b \sigma_{\mathrm{GE}}^{2}$ & MSGE & $\sigma_{\mathrm{GE}}^{2}=0.78$ \\
\hline Error & $(\mathrm{v}-1)(\mathrm{b}-1) \mathrm{L}=688$ & 659.09 & 0.96 & & & $\sigma_{\mathrm{e}}^{2}$ & MSE & $\sigma_{\mathrm{e}}^{2}=0.96$ \\
\hline
\end{tabular}
these could be used in cowpea breeding program to develop new cultivar(s) with higher protein content. Our study provides

Table 1. Analysis of variance for seed protein contents among 173 cowpea genotypes.

EMS $=$ estimated mean square; $\mathrm{G} \times \mathrm{E}=$ gene $\times$ environment; $\mathrm{MSG}$, mean square genotype; MSGE, mean square gene $\times$ environment. 
valuable information for breeders to select and use those germplasms to develop new cowpea cultivars.

Low protein content germplasm was also found in USDA germplasm accessions such as PI 221730, PI 292890, PI 339587, PI 582671, PI 582819, and PI 582850 with protein content from $21.8 \%$ to $22.7 \%$, and all except PI 582819 (Supplemental Table 1) had red Holstein seedcoats.

ANOVA showed that there were significant differences among the cowpea genotypes and the interaction of genotype $\times$ environment (Table 1), suggesting a significant genotype effect and genotype $\times$ environment effect. As shown in Table 1, MSE was 0.96; MSGE was estimated to be 3.30; and MSG was estimated to be 14.12. Broad-sense heritability $\mathrm{H} 2$ for cowpea seed protein among the 173 cowpea genotypes was $\approx 50.8 \%$, indicating the seed protein content was highly inheritable. Ajeigbe et al. (2008) reported that a broadsense heritability in cowpea was $86 \%$ based on

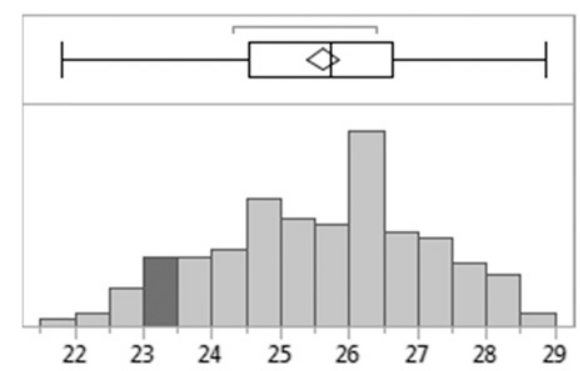

Fig. 1. Distribution of seed protein contents among 173 U.S. Department of Agriculture cowpea germplasm. nine cowpea varieties. Nielsen et al. (1993) had a high broad-sense heritability of $95 \%$ for seed protein in 100 cowpea lines based on data from one location without replication of the study. Tchiagam et al. (2011) determined a broad-sense heritability of $74 \%$ for seed protein using five divergent lines through $5 \times 5$ half diallel cross mating. Emebiri (1991) reported the broad-sense heritability for protein content ranging from $70 \%$ to $78 \%$ in two crosses. In our previous study, the broad-sense heritability was identified as $57.8 \%$ for seed protein content based on 11 Arkansas cowpea lines. All these studies indicate that cowpea has high heritability of seed protein content, suggesting that it is possible to select plants and lines with high seed protein for cowpea breeding programs. The results also show that estimation of the broad-sense heritability dramatically varied among cowpea genotypes from different experiments and studies. In both our studies, we found lower seed protein contents $(50 \%$ to $60 \%)$ than reports from others $(>70 \%)$ due to a high interaction of genotype $\times$ environment observed in our experiments, which decreased the estimated heritability values.

Effects of environment on protein content. In this study, two experimental locations exhibited similar cowpea seed protein content. The mean seed protein content of 173 cowpea accessions in Alma and Fayetteville, $\mathrm{AK}$, were $25.67 \%$ and $25.58 \%$, respectively, a nonsignificant difference between the two locations $(P=0.05)$. The University of Arkansas campus farm in Fayetteville $\left(36^{\circ} 4^{\prime} \mathrm{N}, 94^{\circ} 9^{\prime} \mathrm{S}\right)$ is on the outskirts of the Boston Mountains, deep within the Ozarks. The Vegetable Research Station in Alma

Table 2. Top 10 U.S. Department of Agriculture cowpea germplasm accessions with highest seed protein content.

\begin{tabular}{lcll}
\hline Accession & Protein content $(\%)$ & Seedcoat color & \multicolumn{1}{c}{ Origin } \\
\hline PI662992 & 28.9 & Cream & Florida, USA \\
PI601085 & 28.5 & Browneye & Minnesota, USA \\
PI255765 & 28.4 & Blackeye & Nigeria \\
PI666253 & 28.4 & Cream & Arkansas, USA \\
PI255774 & 28.4 & Browneye & Nigeria \\
PI582942 & 28.3 & Cream & Puerto Rico \\
PI430687 & 28.2 & Red & China \\
PI666251 & 28.1 & Browneye & Virginia, USA \\
PI664519 & 28.1 & Cream & South Carolina, USA \\
PI666269 & 28.0 & Pinkeye & Alabama, USA \\
PI250416 & 28.0 & Cream & Pakistan \\
PI666262 & 28.0 & Pinkeye & Georgia, USA \\
PI339587 (CK) & 21.8 & Red Holstein & South Africa \\
\hline
\end{tabular}

$\left(35^{\circ} 29^{\prime} \mathrm{N}, 94^{\circ} 13^{\prime} \mathrm{S}\right)$ is located in the Arkansas River Valley at the edge of the Ozark Mountains, 50 miles away from the Fayetteville location. There is little difference in weather, temperature, and soil conditions between the two locations. Both are zone $7 \mathrm{a}$ according to the USDA Plant Hardiness Zone Map. The short distance and different conditions between the two locations did not affect seed protein content in cowpea. Different ecological regions and geographic environments should be considered if cowpea protein content is evaluated in future research.

The seed protein content in 173 USDA cowpea germplasm were similar in two experimental locations, with no significant difference was observed between locations. Some germplasm accessions were virtually the same at the two testing sites. For example, there was little difference between PI 250416 and PI 663151 in seed protein content $(0.002 \%$ and $0.010 \%$, respectively) at the two experimental locations. However, there were large differences in some accessions between the two sites. For example, the seed protein content of accession PI 663148 was $26.9 \%$ in Alma and $20.3 \%$ in Fayetteville, respectively, showing a clear difference between the two locations. Similarly, PI 583513 had $28.3 \%$ in Alma and $23.1 \%$ in Fayetteville (Supplemental Table 1).

Interaction between germplasm and location. ANOVA in this study showed that genotype and the genotype $\times$ environment interaction significantly influenced protein content $(P<0.0001)$ (Table 2$)$. However, environmental effect by location was not significantly different due to the close geographic locations of the two sites, which have similar growing environments $(P=0.1196)$. A previous study by Bliss et al. (1973) indicated that there was a significant genotype $\times$ location interaction effect on cowpea protein content. Ddamulira and Santos (2015) also found that protein content in cowpea seeds was significantly affected by the interaction between genotype and environment. Research by Ravelombola et al. (2016) indicated that protein content was significantly different among cowpea genotypes and environment. The data in our study were similar to previous reports indicating that the genotype and interaction between genotype and environment contribute to seed protein content in cowpea. Significant differences in protein content and the interaction

Table 3. Seed protein content parameters by seedcoat color.

\begin{tabular}{|c|c|c|c|c|c|c|c|c|}
\hline Seed color & $\mathrm{N}$ & Mean & SD & Min. & Max. & Variance & SE & $\mathrm{CV}$ \\
\hline$\overline{\text { Black }}$ & 18 & $25.86 b^{z}$ & 1.35 & 23.22 & 29.69 & 1.83 & 0.13 & 5.23 \\
\hline Blackeye & 26 & $25.96 \mathrm{~b}$ & 1.77 & 21.85 & 29.47 & 3.12 & 0.13 & 6.81 \\
\hline Browneye & 29 & $25.96 \mathrm{~b}$ & 1.77 & 21.85 & 29.47 & 3.12 & 0.13 & 6.81 \\
\hline Cream & 12 & $27.23 \mathrm{a}$ & 1.59 & 20.26 & 30.19 & 2.53 & 0.19 & 5.85 \\
\hline Pinkeye & 8 & $26.71 \mathrm{a}$ & 1.55 & 23.50 & 31.01 & 2.39 & 0.21 & 5.79 \\
\hline Red & 15 & $25.25 \mathrm{c}$ & 1.69 & 21.39 & 29.28 & 2.87 & 0.18 & 6.71 \\
\hline Red Holstein & 19 & $23.69 \mathrm{~d}$ & 1.60 & 19.63 & 29.23 & 2.57 & 0.15 & 6.77 \\
\hline Tan & 26 & $25.32 \mathrm{c}$ & 1.67 & 19.98 & 30.86 & 2.78 & 0.13 & 6.59 \\
\hline Varied & 20 & $25.61 \mathrm{bc}$ & 1.40 & 22.01 & 29.11 & 1.95 & 0.13 & 5.46 \\
\hline Merged & 173 & 25.63 & 1.82 & 19.63 & 31.01 & 3.31 & 0.06 & 7.10 \\
\hline
\end{tabular}

${ }^{\mathrm{z}}$ Significant difference at $P=0.05$ level. 
between genotype and environment were also observed in the 173 cowpea genotypes in our study (Table 2), indicating a strong genotype $\times$ environment interaction, although environment (location) effect was not significant.

Relationship between seed protein content and seedcoat color. Seedcoat color varies greatly in cowpea (Mann, 1914) and can be an important indicator of protein content among farmers growing cowpeas and for human consumption. Seedcoat color is not only an important agricultural trait to distinguish different cultivars and genotypes but also a steady indicator of seed nutrition quality. Fery (1985) noted that determining the mechanism of seedcoat pigmentation is complex and difficult to ascertain. Seedcoat color in cowpea is a complex trait, and there may be many genes involved color inheritance (Boukar et al., 2018; Egbadzor et al., 2014). There were at least 12 seedcoat colors recorded in the USDA cowpea germplasm database GRIN. Our results show that there were significant differences among the nine groups of the cowpea seedcoat colors (Table 3). Cream color had the highest protein content among the 173 USDA cowpea accessions $(27.23 \%)$, and pinkeye cowpea was the second highest $(26.71 \%)$. The two highest protein content colors were not significantly different from each other, but they had a total protein content significantly higher than other color types. Brown eye, black eye, and black color were not significantly different from each other and thus represent the third highest accessions in protein content: $25.96 \%, 25.96 \%$, and $25.86 \%$, respectively. Red Holstein color had the lowest seed protein content with 23.61\% dry seed weight, which was significantly lower than other color coats (Table 3). Although cowpea seed protein content cannot be measured by seedcoat color in the marketplace, seedcoat color could provide customers with an indicator of which cowpeas might have higher protein content than others. From this study, we observed the cowpea seeds with cream or pinkeye color contained higher protein contents than others while the red holstein color seed had the least protein content.

\section{Conclusions}

In this study, 173 USDA cowpea germplasm accessions were measured for their seed protein contents. A wide range of seed protein contents was observed, from $21.8 \%$ to $28.9 \%$, with an average of $25.6 \%$. The accessions with the top 10 highest seed protein contents $(\geq 28.4 \%)$ were originally collected from the United States, Nigeria, Puerto Rico, China, and Pakistan. The results indicate that both genotype and the genotype $\times$ environment interaction significantly influence seed protein content in cowpea. However, the environmental effect (location) was not significant due to the close distance and similar growing regions of the two locations in this study. The broad-sense heritability was $50.8 \%$ for the cowpea seed protein content based on 173 cowpea genotypes, indicating that seed protein content was inheritable and could be selected for cowpea breeding. Seedcoat color was also observed to be related to protein content. Cream and pinkeye expressed higher protein contents than other cowpea seedcoat colors, and the red Holstein contained the lowest protein content. These data provide meaningful information for consumers to choose cowpea products with high seed protein content according to different seedcoat colors in the marketplace.

\section{Literature Cited}

Afiukwa, C.A., B. Ubi, K. Kunert, E. Titus, and J. Akusu. 2013. Seed protein content variation in cowpea genotypes. World J. Agr. Sci. 1:9499.

Ajeigbe, H.A., D. Ihedioha, and D. Chikoye. 2008. Variation in physico-chemical properties of seed of selected improved varieties of cowpea as it relates to industrial utilization of the crop. Afr. J. Biotechnol. 7:3642-3647.

Asante, I.K., H. Adu-Dapaah, and P. Addison 2006. Seed weight and protein and tannin contents of 32 cowpea accessions in Ghana. Trop. Sci. 44:77-79.

Bliss, F.A., L.N. Barker, J.D. Franckowiak, and T.C. Hall. 1973. Genetic and environmental variation of seed yield, yield components and seed protein quantity and quality of cowpea. Crop Sci. 13:656-660.

Boukar, O., N. Belko, S. Chamarthi, A. Togola, J. Batieno, E. Owusu, M. Haruna, S. Diallo, M.L. Umar, O. Olufajo, and C. Fatokun. 2018. Cowpea (Vigna unguiculata): Genetics, genomics and breeding. Plant Breed. $<\mathrm{https}$ // onlinelibrary.wiley.com/doi/full/10.1111/ pbr.12589>.

Ddamulira, G. and C. Santos. 2015. Grain yield and protein content of Brazilian cowpea genotypes under diverse Ugandan environments. AJPS 6:2074-2084.

Egbadzor, K.F., K. Ofori, M. Yeboah, L.M. Aboagye, M.O. Opoku-Agyeman, E.Y. Danquah, and S.K. Offei. 2014. Diversity in 113 cowpea [Vigna unguiculata (L) Walp] accessions assessed with 458 SNP markers. Springerplus 3:541.

Emebiri, L.C. 1991. Inheritance of protein content in seeds of selected crosses of cowpea Vigna unguiculata L. Walp. J. Sci. Food Agr. $54: 1-7$.

Fang, J., C.T. Chao, P.A. Roberts, and J.D. Ehlers. 2007. Genetic diversity of cowpea [Vigna unguiculata (L.) Walp.] in four West African and USA breeding programs as determined by AFLP analysis. Genet. Resources Crop Evol. 54:1197-1209.

Fery, R.L. 1985. Improved cowpea cultivars for the horticultural industry in the USA, p. 129-135. In: S.R. Singh, K.O. Rachie (eds.). Cowpea research, production and utilization. John Wiley \& Sons, Inc., New York.

Fery, R.L. 1993. Bettergreen Southernpea. HortScience 28:62-63.

Gupta, P., R. Singh, S. Malhotra, K.S. Boora, and H.R. Singal. 2010. Characterization of seed storage proteins in high protein genotypes of cowpea [Vigna unguiculata (L.) Walp.]. Physiol. Mol. Biol. Plants 16:53-58.

Horneck, D. and R. Miller. 1998. Determination of total nitrogen in plant tissue, p. 75-83. In: Y.P. Kalra (ed.). Handbook of reference methods for plant analysis. CRC Press, New York.

Itatat, S.L., E.C. Nworgu, E.N. Ikpe, and J.A. Osakwe. 2013. Evaluation of the protein contents of selected cowpea (Vigna unguiculata (L.) Walp.) varieties for production in Port Harcourt. Acta Agronomica Nigeriana 13:71-75.

Kushwaha, A. and A. Kumar. 2014. Development of high protein biscuits from cowpea (Vigna unguiculata) flour. Intl. J. Basic Appl. Agr. Res. 12(2):288-291.

Mann, A. 1914. Coloration of the seed coat of cowpeas. J. Agr. Res. 2:33-56.

Moore, J.C., J.W. DeVries, M. Lipp, J.C Griffiths, and D.R. Abernethy. 2010. Total protein methods and their potential utility to reduce the risk of food protein adulteration. Compr. Rev. Food Sci. Food Saf. 9:330-357.

Nielsen, S., T. Ohler, and C. Mitchell. 1997. Cowpea leaves for human consumption: Production, utilization, and nutrient composition, p. 326-332. In: B.B. Singh, D.R. Mohan Raj, K.E. Dashiell, and L.E.N. Jackai (eds.). Advances in cowpea research. International Institute of Tropical Agriculture, Ibidan, Nigeria.

Nielsen, S.S., W.E. Brandt, and B.B. Singh. 1993. Genetic variability for nutritional composition and cooking time in improved cowpea lines. Crop Sci. 33:469-472.

Oke, D., O. Tewe, and B. Fetuga. 2015. The nutrient composition of some cowpea varieties. Niger. J. Anim. Prod. 22:32-36.

Ravelombola, W., A. Shi, Y. Weng, D. Motes, P. Chen, V. Srivastava, and C. Wingfield. 2016. Evaluation of total seed protein content in eleven Arkansas cowpea (Vigna unguiculata (L.) Walp.) lines. AJPS 7:2288-2296.

Singh, M., S. Ceccarelli, and J. Hamblin. 1993. Estimation of heritability from varietal trials data. Theor. Appl. Genet. 86:437-441.

Singh, B.B., D.R. Mohan Raj, K.E. Dashiell, and L.E.N. Jackai. 1997. Advances in Cowpea Research. International Institute of Tropical Agriculture, Ibadan, Nigeria, and Japan International Research Center for Agricultural Sciences Tsukuba, Ibaraki, Japan.

Tchiagam, J.B.N., J.M. Bell, A.M. Nassourou, N.Y. Njintang, and E. Youmbi. 2011. Genetic analysis of seed proteins contents in cowpea Vigna unguiculata L. Walp. Afr. J. Biotechnol. 1016:3077-3086.

Weng, Y., A. Shi, W. Ravelombola, W. Yang, J. Qin, D. Motes, D.O. Moseley, and P. Chen. 2017. A rapid method for measuring seed protein content in cowpea (Vigna unguiculata (L.) Walp). AJPS 8:2387-2396. 
Supplemental Table 1. Seed protein content in 173 cowpea germplasm accessions.

\begin{tabular}{|c|c|c|}
\hline Accession & Seed color & Protein content $(\%)$ \\
\hline$\overline{\text { PI291140 }}$ & Black & 25.2 \\
\hline PI292898 & Black & 26.1 \\
\hline PI339588 & Black & 25.4 \\
\hline PI349674 & Black & 24.4 \\
\hline PI354673 & Black & 26.1 \\
\hline PI354832 & Black & 27.9 \\
\hline PI354835 & Black & 26.5 \\
\hline PI354843 & Black & 26.1 \\
\hline PI354860 & Black & 26.6 \\
\hline PI354864 & Black & 24.8 \\
\hline PI354865 & Black & 25.5 \\
\hline PI427093 & Black & 27.9 \\
\hline PI582474 & Black & 25.4 \\
\hline PI582575 & Black & 27.1 \\
\hline PI583197 & Black & 27.4 \\
\hline PI583232 & Black & 24.2 \\
\hline PI610520 & Black & 25.8 \\
\hline PI610620 & Black & 24.5 \\
\hline PI201498 & Blackeye & 23.1 \\
\hline PI229734 & Blackeye & 26.0 \\
\hline PI253428 & Blackeye & 27.0 \\
\hline PI255765 & Blackeye & 28.4 \\
\hline PI262179 & Blackeye & 26.2 \\
\hline PI293477 & Blackeye & 26.1 \\
\hline PI293505 & Blackeye & 26.0 \\
\hline PI293586 & Blackeye & 26.7 \\
\hline PI293588 & Blackeye & 26.5 \\
\hline PI406285 & Blackeye & 26.0 \\
\hline PI582352 & Blackeye & 26.6 \\
\hline PI582353 & Blackeye & 25.8 \\
\hline PI582422 & Blackeye & 25.4 \\
\hline PI582428 & Blackeye & 27.5 \\
\hline PI582466 & Blackeye & 26.0 \\
\hline PI582551 & Blackeye & 25.0 \\
\hline PI582923 & Blackeye & 26.2 \\
\hline PI583200 & Blackeye & 24.5 \\
\hline PI583513 & Blackeye & 25.7 \\
\hline PI608035 & Blackeye & 24.3 \\
\hline PI610533 & Blackeye & 25.7 \\
\hline PI642160 & Blackeye & 26.1 \\
\hline PI663101 & Blackeye & 26.6 \\
\hline PI663148 & Blackeye & 23.6 \\
\hline PI664517 & Blackeye & 26.8 \\
\hline PI664524 & Blackeye & 26.9 \\
\hline PI218123 & Browneye & 24.9 \\
\hline PI220851 & Browneye & 23.0 \\
\hline PI223023 & Browneye & 24.0 \\
\hline PI255774 & Browneye & 28.4 \\
\hline PI293470 & Browneye & 24.8 \\
\hline PI312210 & Browneye & 25.6 \\
\hline PI339599 & Browneye & 27.9 \\
\hline PI406290 & Browneye & 26.1 \\
\hline PI582512 & Browneye & 27.1 \\
\hline PI582570 & Browneye & 25.9 \\
\hline PI582573 & Browneye & 27.7 \\
\hline PI582667 & Browneye & 25.0 \\
\hline PI582814 & Browneye & 24.9 \\
\hline PI582855 & Browneye & 25.5 \\
\hline PI582857 & Browneye & 25.8 \\
\hline PI582861 & Browneye & 27.5 \\
\hline PI582863 & Browneye & 25.3 \\
\hline PI582926 & Browneye & 26.9 \\
\hline PI582932 & Browneye & 24.4 \\
\hline PI583201 & Browneye & 27.3 \\
\hline PI583202 & Browneye & 23.1 \\
\hline PI583248 & Browneye & 26.1 \\
\hline PI583249 & Browneye & 26.2 \\
\hline PI583274 & Browneye & 24.1 \\
\hline PI601085 & Browneye & 28.5 \\
\hline PI601453 & Browneye & 26.2 \\
\hline PI663011 & Browneye & 23.9 \\
\hline PI663059 & Browneye & 27.8 \\
\hline PI666251 & Browneye & 28.1 \\
\hline
\end{tabular}

(Continued on next page)
Supplemental Table 1. (Continued) Seed protein content in 173 cowpea germplasm accessions.

\begin{tabular}{llc}
\hline Accession & Seed color & Protein content (\%) \\
\hline PI250416 & Cream & 28.0 \\
PI582924 & Cream & 27.3 \\
PI582942 & Cream & 28.3
\end{tabular}

PI592369 Cream 24.5

PI592374 Cream 26.1

PI662992 Cream 28.9

PI663140 Cream 25.5

PI663151 Cream 27.1

PI664515 Cream 26.6

PI664518 Cream 26.7

PI664519 Cream 28.1

PI666253 Cream 28.4

PI582525 Pinkeye 24.9

PI582931 Pinkeye 26.8

PI663150 Pinkeye 26.6

PI664513 Pinkeye 26.2

PI664514 Pinkeye 26.8

PI666260 Pinkeye 27.3

PI666262 Pinkeye 28.0

PI666269 Pinkeye 28.0

PI152195 Red 23.4

PI152197 Red 25.4

PI293587 Red 24.9

PI311119 Red 25.6

PI339605 Red 23.0

PI354805 Red 24.1

PI354854 Red 24.3

PI354855 Red 25.2

PI430687 Red 28.2

PI578902 Red 25.6

PI578911 Red 25.1

PI582702 Red 27.5

PI582815 Red 26.9

PI582868 Red 23.5

PI583195 Red 25.9

PI202802 Red Holstein 24.7

PI220850 Red Holstein 24.0

PI221730 Red Holstein 22.1

PI221731 Red Holstein 23.5

PI257463 Red Holstein 23.8

PI292890 Red Holstein 22.5

PI292892 Red Holstein 23.1

PI339587 Red Holstein 21.8

PI339591 Red Holstein 23.4

PI582423 Red Holstein 23.2

PI582468 Red Holstein 27.6

PI582671 Red Holstein 22.7

PI582703 Red Holstein 23.5

PI582812 Red Holstein 23.4

PI582822 Red Holstein 23.5

PI582823 Red Holstein 25.1

PI582824 Red Holstein 23.1

PI582850 Red Holstein $\quad 22.2$

PI582858 Red Holstein 23.7

PI180014 Tan 26.4

PI190191 Tan 24.7

PI292894 Tan 26.0

PI292899 Tan 27.0

PI292913 Tan 26.1

PI300173 Tan 25.2

PI354580 Tan 24.2

PI367921 Tan 26.3

PI527561 Tan 26.2

PI582402 Tan 26.2

PI582415 Tan 24.4

\begin{tabular}{lll} 
PI582425 Tan & 24.3 \\
\hline
\end{tabular}

PI582465 Tan 26.3

$\begin{array}{lll}\text { PI582572 Tan } & 26.4\end{array}$

PI582697 Tan 26.6

PI582735 Tan 23.4

PI582789 Tan 23.5

$\begin{array}{lll}\text { PI582819 Tan } & 22.7\end{array}$

\begin{tabular}{lll} 
PI582825 Tan & 23.0 \\
\hline
\end{tabular}
Supplemental Table 1. (Continued) Seed protein content in 173 cowpea germplasm accessions.

\begin{tabular}{llc}
\hline Accession & Seed color & Protein content (\%) \\
\hline PI582852 & Tan & 25.5 \\
PI582874 & Tan & 23.9 \\
PI582894 & Tan & 24.7 \\
PI583209 & Tan & 27.4 \\
PI583240 & Tan & 27.3 \\
PI583244 & Tan & 26.0 \\
PI583550 & Tan & 24.8 \\
PI152196 & Variable & 26.3 \\
PI167284 & Variable & 23.7 \\
PI227829 & Variable & 26.4 \\
PI244571 & Variable & 25.7 \\
PI292897 & Variable & 25.6 \\
PI293476 & Variable & 26.1 \\
PI293514 & Variable & 24.8 \\
PI293545 & Variable & 24.7 \\
PI293570 & Variable & 25.2 \\
PI293582 & Variable & 23.3 \\
PI293584 & Variable & 26.5 \\
PI339610 & Variable & 24.6 \\
PI582417 & Variable & 25.7 \\
PI582420 & Variable & 26.2 \\
PI582421 & Variable & 25.7 \\
PI582521 & Variable & 25.5 \\
PI582530 & Variable & 27.2 \\
PI582821 & Variable & 24.9 \\
PI582856 & Variable & 26.8 \\
PI583199 & Variable & 27.3 \\
\hline & &
\end{tabular}

(Continued on next page) 